\title{
HIDROLISIS HASIL DELIGNIFIKASI TANDAN KOSONG KELAPA SAWIT DALAM SISTEM CAIRAN IONIK CHOLINE CHLORIDE
}

\author{
Gendish Yoricya $^{1)}$, Shinta Aisyah Putri Dalimunthe ${ }^{1)}$, Renita Manurung ${ }^{1)}$, Nimpan Bangun ${ }^{2)}$ \\ ${ }^{1}$ Departemen Teknik Kimia, Fakultas Teknik, Universitas Sumatera Utara, \\ Jl. Almamater Kampus USU, Medan 20155, Indonesia \\ ${ }^{2}$ Departemen Kimia, Fakultas Teknik, Universitas Sumatera Utara, \\ Jl.Bioteknologi Kampus USU, Medan 20155, Indonesia \\ Email: gendishyoricya@yahoo.com
}

\begin{abstract}
Abstrak
Tandan Kosong Kelapa Sawit (TKKS) merupakan limbah pertanian yang memiliki kandungan lignoselulosa yang cukup tinggi. TKKS ini belum dimanfaatkan secara maksimal. Dengan kandungan selulosa sebesar 45-50\%, maka TKKS berpotensi untuk digunakan sebagai bahan baku pembuatan bioetanol. Dalam proses pembuatan bioetanol, delignifikasi lignoselulosa adalah tahap pertama yang dilakukan untuk memutuskan ikatan antara selulosa, hemiselulosa, dan lignin. Pada penelitian ini dilakukan proses delignifikasi menggunakan $\mathrm{NaOH}$ dalam sistem cairan ionik dan tanpa cairan ionik. Penelitian ini bertujuan untuk memperoleh kadar selulosa tertinggi yang terdapat pada TKKS dan menentukan pengaruh hidrolisis selulosa hasil delignifikasi tandan kosong kelapa sawit dan menentukan kondisi terbaik hidrolisis yang didapatkan pada proses hidrolisis dalam sistem cairan ionik kolin klorid. Proses delignifikasi yang dilakukan menggunakan cairan ionik kolin klorida $(\mathrm{ChCl})$ dalam berbagai waktu pemasakan dengan jumlah $\mathrm{ChCl}$ yang berbeda. Penelitian ini menggunakan serbuk TKKS yang dimasak pada suhu $130{ }^{\circ} \mathrm{C}$ dengan variasi waktu pemasakan 30,60, dan 90 menit dan variasi penambahan $\mathrm{ChCl}$ sebesar $10 \%$, $15 \%$, dan $20 \%$ dari berat TKKS. Hasil penelitian delignifikasi menggunakan $\mathrm{ChCl}$ diperoleh kadar selulosa tertinggi yaitu 40,33\%, dengan kandungan hemiselulosa $20,03 \%$, dan lignin $3,62 \%$ pada perlakuan pemasakan 90 menit dan penambahan $\mathrm{ChCl} 15 \%$. Sedangkan delignifikasi tanpa $\mathrm{ChCl}$ memperoleh kadar selulosa tertinggi yang diperoleh yaitu 24,98\%, kandungan hemiselulosa $8,25 \%$, dan lignin $18,99 \%$ pada perlakuan pemasakan 90 menit. Proses delignifikasi menggunakan cairan ionik $\mathrm{ChCl}$ mampu meningkatkan derajat delignifikasi sebesar 61,45. Pada proses hidrolisis bahan baku utama yang digunakan adalah selulosa hasil delignifikasi TKKS, kolin klorida, asam sulfat, dan aquadest. Penelitian ini dilakukan pada temperatur $105^{\circ} \mathrm{C}$, konsentrasi katalis $\left(\mathrm{H}_{2} \mathrm{SO}_{4}\right) 10 \%$ (b/b) selulosa, jumlah cairan ionik $10 \%, 15 \%$, dan $20 \%$ (b/b) selulosa dan kecepatan pengaduk konstan 120 rpm dengan waktu reaksi 30, 60 dan 90 menit. Hasil penelitian pada tahap hidrolisis menggunakan cairan ionik diperoleh kadar glukosa. Analisis dengan metode LUFF menunjukkan kadar glukosa maksimum yang dihasilkan yaitu sebesar 37,96\% dengan kondisi terbaik pada waktu reaksi 90 menit dan jumlah kolin klorid 20\%.
\end{abstract}

Kata kunci : Tandan Kosong Kelapa Sawit (TKKS), lignoselulosa, delignifikasi, kolin klorida, cairan ionik

\footnotetext{
Abstract

Palm Empty Fruit Bunches (TKKS) was the waste which has a fairly high content of lignocelluloses. Meanwhile, TKKS has not been utilize optimally. With a cellulose content of 45\%$50 \%$, TKKS then potentially be used as raw material for bioethanol. In the process of production bioethanol, delignification of lignocellulose the first phase was conducted to dissolve ligament between cellulose, hemicellulose and lignin. In this research, delignification process was carried out using $\mathrm{NaOH}$ in the ionic liquid system and without ionic liquids. The purpose of this research was to find out the highest content of cellulose which contained in the TKKS and to determine the hydrolysis of delignification results on palm empty fruit bunches and the best hydrolysis conditions was obtained at the hydrolysis process in the choline chloride ionic liquid system. Delignification process were performed using ionic liquids choline chloride $(\mathrm{ChCl})$ in variety of cooking time with amount different $\mathrm{ChCl}$. This research used TKKS powder cooked at a temperature $130{ }^{\circ} \mathrm{C}$ with a variety of cooking time 30, 60, and 90 minutes and the variation of $\mathrm{ChCl} 10 \%, 15 \%$ and 20\% weight of TKKS. Delignification research results used ChCl obtained highest content of cellulose was $40,33 \%$, hemicellulose 20,28\%, and lignin 3,62\% in cooking treatment 90 minutes and 15\% $\mathrm{ChCl}$. While delignification without ChCl obtained highest content of cellulose is 24,98\%, hemicellulose 8,25\%, and lignin 18,99\% in cooking treatment 90 minutes. Delignification process using $\mathrm{ChCl}$ be able increase the degree of delignification as big as 61,45\%. In the hydrolisis process, the main raw material used cellulose of delignification TKKS result, choline chloride, sulfatl acid, and distilled water. The hydrolysis stage in this research was carried out at temperature $105^{\circ} \mathrm{C}$, catalyst (H2SO4) $10 \%(w / w)$ cellulose, ChCl 10\%, 15\%, and $20 \%(w / w)$ cellulose and it was stirred at constant speed 120 rpm with reaction time of 30, 60 and 90 minutes. The result in the hydrolysis stage using ionic liquid obtained glucose. LUFF method analysis
} 
showed the maximum result of glucose $37.96 \%$ with the best conditions in reaction time 90 minutes and the amount of choline chloride $20 \%$.

\section{Keywords : Palm Oil Empty Fruit Bunches, lignocellulose, delignification, choline chloride, ioniq liquid}

\section{Pendahuluan}

Tandan kosong kelapa sawit (TKKS) merupakan limbah industri Crude Palm Oil (CPO) dan limbah perkebunan kelapa sawit. Jumlah tandan kosong kelapa sawit yang dihasilkan sebanyak 23-30\% dari tandan buah segar. Perluasan areal kelapa sawit makin gencar dilakukan di era tahun 2013 yang berarti semakin banyak pula jumlah tandan kosong kelapa sawit yang dihasilkan [6].

Tandan kosong kelapa sawit merupakan limbah berlignoselulosa yang belum termanfaatkan secara optimal. Selama ini pemanfaatan tandan kosong hanya sebagai bahan bakar boiler, kompos dan juga sebagai pengeras jalan di perkebunan kelapa sawit. Dengan kandungan selulosa sebesar 45,95\%, maka TKKS berpotensi untuk digunakan sebagai bahan baku pembuatan bioetanol [2].

Dalam proses pembuatan bioetanol, delignifikasi lignoselulosa adalah tahap pertama yang dilakukan untuk memutuskan ikatan antara selulosa, hemiselulosa, dan lignin. Proses delignifikasi merupakan proses penghilangan lignin dari bahan baku sehingga hasil dari proses ini berupa selulosa dengan kemurnian yang cukup besar [5]. Delignifikasi selulosa dalam media Ionic Liquid (cairan ionik) lebih efektif dibandingkan tanpa Ionic Liquid. Cairan ionik adalah garam yang pada suhu kamar berbentuk cair. Hal ini disebabkan cairan ionik telah menurunkan derajat kristalinitas dan meningkatkan porositas sampel sehingga lebih mudah mendelegnifikasi TKKS [4]. Hidrolisis memegang peranan yang tidak kalah penting dalam pembuatan bioetanol. TKKS mempunyai potensi untuk digunakan sebagai sumber glukosa melalui proses hidrolisis dengan asam atau enzim. Larutan gula yang dihasilkan selanjutnya dapat dikonversi menjadi berbagai produk seperti alkohol, yang mempunyai nilai ekonomis jauh lebih tinggi. Hidrolisis lignoselulosa dengan asam encer adalah cara yang paling umum diaplikasikan untuk mendapatkan gula .

Cairan ionik umumnya dapat digunakan pada suhu kamar dan tidak menghasilkan reaksi samping yang bersifat toksik [4]. Cairan ionik kolin klorida merupakan asam lemah yang mempunyai tingkat toksiksitas yang rendah, dan ramah lingkungan.

\section{Teori}

Pada Tahapan awal yang dilakukan dalam produksi bioetanol adalah proses delignifikasi. Delignifikasi merupakan suatu proses pembebasan lignin dari suatu senyawa kompleks atau material berlignoselulosa sehingga hasil dari proses ini sudah berupa selulosa dengan kemurnian yang cukup besar [5]. Selulosa merupakan polisakarida yang didalamnya mengandung zat - zat gula. Dalam pembuatan bioetanol yang digunakan adalah selulosanya sehingga lignin dalam TKKS harus dihilangkan [3].

Lignin dapat membentuk ikatan kovalen dengan beberapa komponen hemiselulosa. Oleh karena itu lignin sangat sulit untuk didegradasi. Sehingga keberadaannya memberikan bentuk lignoselulosa yang kompleks dan menghambat degradasi selulosa oleh mikroba ataupun bahan kimia lainnya [7].

Proses delignifikasi terdiri dari proses mekanis, semi kimia, kimia (alkali, sulfat/kraft, sulfit) dan proses konvensional yang lebih berwawasan lingkungan. Pada kenyataannya, proses delignifikasi secara konvensional tersebut memiliki beberapa kelemahan, yaitu biaya produksi tinggi, laju delignifikasi rendah dan pencemaran lingkungan karena adanya limbah larutan pemasak [7].

Lignin umumnya tidak larut dalam pelarut sederhana, namun lignin larut dalam alkali encer, larutan garam dan buffer. Lignin larut dalam pelarut organik didasarkan pada perbedaan kelarutan komponen kimia bahan baku, dimana lignin dan ekstraktif larut dalam pelarut organik, karbohidrat dengan bobot molekul rendah dapat larut dalam air sedangkan selulosa tidk larut dalam kedua larutan tersebut [3].

Cairan ionik adalah garam yang berwujud cair pada suhu kamar atau di bawah suhu kamar, terdiri dari kation organik dan anion organik atau anorganik [3]. Delignifikasi menggunakan cairan ionik choline chloride $(\mathrm{ChCl})$ disebabkan oleh interaksi pengikatan radikal bebas serat antara $\mathrm{Cl}$ dengan grup hidroksil pada lignin, sehingga ikatan lignin terputus dan menyebabkan kadar selulosa meningkat.

Bioetanol dihasilkan dari tahapan- tahapan proses, yaitu pretreatmen, hidrolisis, fermentasi, dan destilasi. Semua tahapan - tahapan tersebut sangat diperlukan untuk pembuatan bioetanol. Namun tahap hidrolisis memegang peranan yang tidak kalah penting dalam pembuatan bioetanol. TKKS mempunyai potensi untuk digunakan sebagai sumber glukosa melalui proses hidrolisis dengan asam atau enzim. Larutan gula yang dihasilkan selanjutnya dapat dikonversi menjadi berbagai produk seperti alkohol, yang mempunyai nilai ekonomis jauh lebih tinggi. Hidrolisis lignoselulosa dengan asam encer adalah cara yang paling umum diaplikasikan untuk mendapatkan gula. Hidrolisis asam encer dilakukan 
menggunakan asam mineral seperti $\mathrm{H}_{2} \mathrm{SO}_{4}$ dan $\mathrm{HCl}$ pada suhu antara $120-200{ }^{\circ} \mathrm{C}$.

Hidrolisis adalah pemecahan rantai polisakarida menjadi monosakarida-monosakarida menggunakan air. Pada hidrolisis sempurna selulosa akan menghasilkan glukosa, sedangkan hemiselulosa menghasilkan beberapa monomer gula pentose (C5) dan heksosa (C6). Hidrolisis dapat dilakukan secara kimia (asam) atau enzimatik. Hidrolisis tandan kosong sawit adalah representasi dari proses delignifikasi yaitu memisahkan serat (selulosa dan fragmentasinya) yang terdapat dalam kayu dari senyawa lignin.

Hidrolisis selulosa dalam media Ionic Liquid (cairan ionik) lebih efektif dibandingkan tanpa Ionic Liquid. Cairan ionik adalah garam yang pada suhu kamar berbentuk cair.

\section{Metodologi Penelitan}

\section{Alat dan Bahan}

Alat yang digunakan adalah neraca analitik, ball mill, ayakan, kertas saring, hot plate, oven, tanur, dan alat-alat gelas yang umum digunakan dalam laboratorium kimia, aluminium foil, batang pengaduk, timbangan, termometer, magnetic stirrer, labu leher empat, refluks kondensor, beaker glass, statif dan klem, gelas ukur, erlenmeyer, kertas saring, pipet tetes, gabus, corong gelas dan oven.

Bahan baku yang digunakan dalam penelitian adalah Tandan Kosong Kelapa Sawit (TKKS). Bahan kimia yang digunakan antara lain: aquadest, kolin klorida, natrium peroksida 3\%, dan asam sulfat $72 \%$, Selulosa hasil delignifikasi asam sulfat $\left(\mathrm{H}_{2} \mathrm{SO}_{4} 97 \%\right)$, kalium iodida(KI20\%), Natrium tiosulfat $\left(\mathrm{NH}_{4}\right)_{2} \mathrm{HPO}_{4}$, indikator kanji , Larutan Luff, Aquadest $\left(\mathrm{H}_{2} \mathrm{O}\right)$.

\section{Prosedur Delignifikasi Menggunakan $\mathrm{NaOH}$ Tanpa Cairan Ionik}

Serbuk TKKS ditimbang sebanyak 30 gram, kemudian dimasukkan ke dalam gelas kimia, lalu larutans $\mathrm{NaOH} 3 \%$ sebanyak $150 \mathrm{ml}$ ditambahkan ke dalam gelas kimia yang berisi serbuk TKKS. Kemudian campuran diaduk dengan rata sampai merendam serbuk. Serbuk direndam dalam larutan $\mathrm{NaOH} \mathrm{3 \%}$ selama waktu yang sudah ditentukan. Serbuk yang sudah direndam dengan $\mathrm{NaOH} 3 \%$ dicuci dengan air dan dikeringkan pada suhu $105{ }^{\circ} \mathrm{C}$ selama 16 jam sebelum digunakan.

\section{Prosedur Delignifikasi Menggunakan $\mathrm{NaOH}$ Dalam Sistem Cairan Ionik}

Serbuk TKKS ditimbang sebanyak 30 gram, kemudian dimasukkan ke dalam gelas kimia. Lalu larutan $\mathrm{NaOH} 3 \%$ sebanyak $150 \mathrm{ml}$ ditambahkan ke dalam gelas kimia yang berisi serbuk TKKS. Kemudian campuran diaduk dengan rata sampai merendam serbuk selama 90 menit. Serbuk yang sudah direndam dengan $\mathrm{NaOH} \mathrm{3 \%}$ dicuci dengan air dan dikeringkan pada suhu $105{ }^{\circ} \mathrm{C}$ selama 16 jam sebelum digunakan. Serbuk diayak, dicampurkan dengan cairan ionik kolin klorida, dipanaskan sampai suhu $130{ }^{\circ} \mathrm{C}$ selama waktu yang sudah ditentukan. Setelah itu serbuk dicuci dengan air untuk menghilangkan cairan ionik untuk mendapatkan selulosa. Dicuci lagi dengan air, lalu dimasukkan ke dalam oven sampai berat konstan.

Analisis selulosa, hemiselulosa, dan lignin dilakukan menggunakan metode Chesson-Datta.

\section{Prosedur Hidrolisis}

Sejumlah 10 gr selulosa hasil delignifikasi TKKS dimasukkan dalam Erlemmeyer $250 \mathrm{ml}$. Ditambah asam sulfat pekat sebanyak $10 \%$ dari berat sampel yang telah diencerkan dengan aquades dan cairan ionik kolin kloride sebanyak jumlah yang telah ditentukan kedalam Erlemmeyer $250 \mathrm{ml}$. Kemudian erlenmeyer tersebut ditutup dengan gabus dan dipanaskan pada suhu $105{ }^{\circ} \mathrm{C}$ sambil diaduk menggunakan magnetic stirerr selama waktu yang telah ditentukan. Kemudian diukur $\mathrm{pH}$ sampel yang telah dihidrolisis hingga mencapai $\mathrm{pH}$ 7. Setelah itu hasil hidrolisis tersebut disaring menggunakan kertas saring dan diperoleh filtrat polisakarida. Kemudian dilakukan analisa kadar glukosa menggunakan metode Luff Schoorl.

\section{Analisis Kadar Glukosa}

Ditimbang sebanyak 2 gr sampel dan dimasukkan ke dalam labu ukur $250 \mathrm{ml}$, ditambahkan air dan dihomogenkan. Ditambahkan $5 \mathrm{ml} \mathrm{Pb}$-asetat setengah basa dan digoyang.

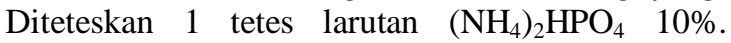
Digoyang dan ditepatkan isi labu ukur sampai tanda garis batas dengan aquades, dikocok 12 kali dan disaring. Dipipet larutan hasil penyaringan dan dimasukkan ke dalam erlenmeyer $500 \mathrm{ml}$. Ditambahkan $15 \mathrm{ml}$ aquades dan $25 \mathrm{ml}$ larutan Luff serta beberapa butir batu didih. Dihubungkan erlenmeyer dengan pendingin tegak, di panaskan diatas pemanas listrik sampai mendidih selama 10 menit. Dipanaskan terus sampai 10 menit, kemudian diangkat dan didinginkan. Setelah dingin ditambahkan $10 \mathrm{ml}$ larutan KI $20 \%$ dan $25 \mathrm{ml}$ larutan $\mathrm{H}_{2} \mathrm{SO}_{4} 25 \%$. Di titrasi dengan larutan tio $0,0990 \mathrm{~N}$ dengan larutan kanji 0,5\% sebagai indikator. Dibuat larutan blanko dengan $25 \mathrm{ml}$ air dan $25 \mathrm{ml}$ larutan luff dengan cara yang sama tanpa menggunakan larutan sampel. Dihitung kadar glukosa yang didapat dengan menggunakan persamaan 1 .

$\%$ Glukosa $=\frac{\mathrm{W} 1 \mathrm{xfp}}{\mathrm{W}} \times 100 \%$

Dimana :

$\mathrm{W}_{1}=$ Glukosa $(\mathrm{mg})$

$\mathrm{Fp}=$ Faktor pengenceran

$\mathrm{W}=$ Bobot contoh $(\mathrm{mg})$ 
Analisa yang dilakukan adalah untuk mengetahui kadar glukosa dilakukan dengan metode Luff Schoorl.

\section{Hasil dan Pembahasan}

Pengaruh Jumlah Kolin Klorida (ChCl) dan Waktu Delignifikasi Terhadap Kadar Lignin yang Tertinggal di Dalam Holoselulosa

Proses delignifikasi Tandan Kosong Kelapa Sawit (TKKS) dilakukan menggunakan $\mathrm{NaOH}$ dalam sistem cairan ionik kolin klorida $(\mathrm{ChCl})$ pada berbagai variasi jumlah $\mathrm{ChCl}$, yaitu $10 \%$, $15 \%$, dan $20 \%$ berat TKKS. Hasil penelitian menunjukkan bahwa jumlah cairan ionik yang berbeda berpengaruh terhadap lignin yang dihasilkan. Berikut adalah grafik yang menunjukkan hubungan antara kadar lignin yang tertinggal di dalam holoselulosa dengan jumlah $\mathrm{ChCl}$ dan waktu delignifikasi.

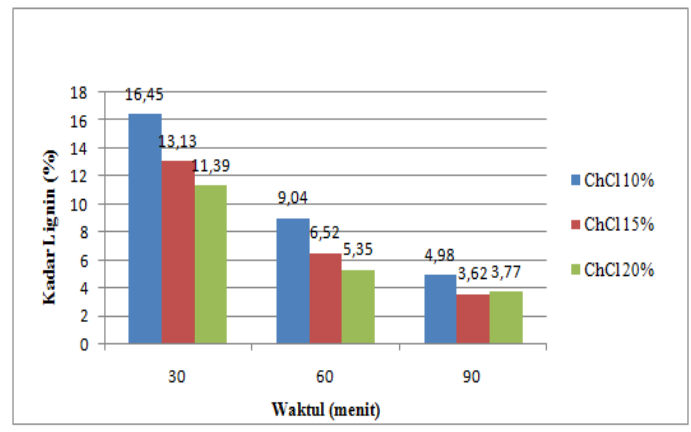

Gambar 1(a). Pengaruh jumlah $\mathrm{ChCl}$ dan Waktu Delignifikasi Terhadap Kadar Lignin yang Tertinggal di Dalam Holoselulosa

Pada proses delignifikasi TKKS dalam sistem $\mathrm{ChCl}$ ini diharapkan dapat dihasilkan selulosa dengan kandungan lignin yang rendah. Gambar 1(a) menunjukkan bahwa kadar lignin menurun seiring peningkatan jumlah $\mathrm{ChCl}$. Penurunan kadar lignin disebabkan waktu pemasakan yang cukup lama memicu terjadinya degradasi gugus basa dari larutan pemasak yang menyerang alfa dan beta lignin, sehingga hasil degradasi tidak stabil memicu terjadinya kondensasi. Kondensasi menyebabkan putusnya ikatan lignin dari hemiselulosa dan selulosa. Dan karena $\mathrm{ChCl}$ bersifat asam, pada suasana asam bobot molekul lignin cenderung bertambah. Peristiwa ini menyebabkan lignin mengendap, lalu larut dalam air proses pencucian.

Namun, dengan jumlah $\mathrm{ChCl}$ lebih dari 15\% menyebabkan kadar lignin yang tertinggal di dalam holoselulosa konstan pada waktu 90 menit akibat terjadinya reaksi adisi gugus hidroksil yang menyebabkan lignin tidak ikut larut dalam air pencucian [1]. Kandungan lignin yaitu sekitar $18 \%$ - 20\% berat TKKS. Lignin yang dihasilkan berkisar antara $3,77 \%$ hingga $16,45 \%$. Dari hasil penelitian ini didapatkan yield lignin yang dihasilkan dari proses delignifikasi menggunakan $\mathrm{ChCl}$ yaitu sebesar $79,88 \%-81,9 \%$.

Pengaruh Jumlah Kolin Klorid (ChCl) dan Waktu Delignifikasi Terhadap Kadar Selulosa dan Kadar Hemiselulosa

Berikut adalah grafik yang menunjukkan hubungan antara kadar selulosa dan hemiselulosa dengan jumlah $\mathrm{ChCl}$ dan waktu delignifikasi.

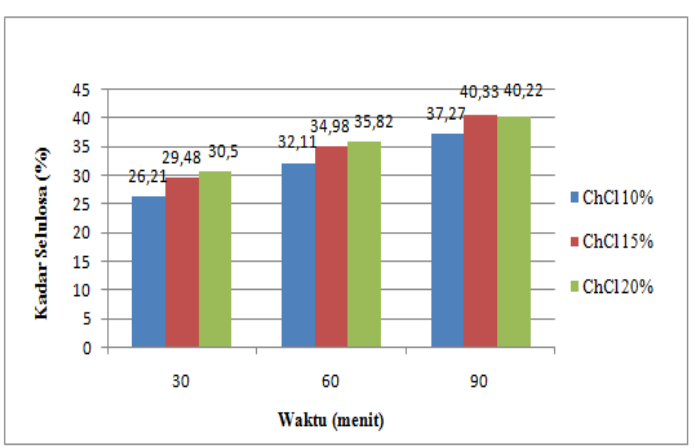

Gambar 1(b). Pengaruh jumlah $\mathrm{ChCl}$ dan Waktu Delignifikasi Terhadap Kadar Selulosa

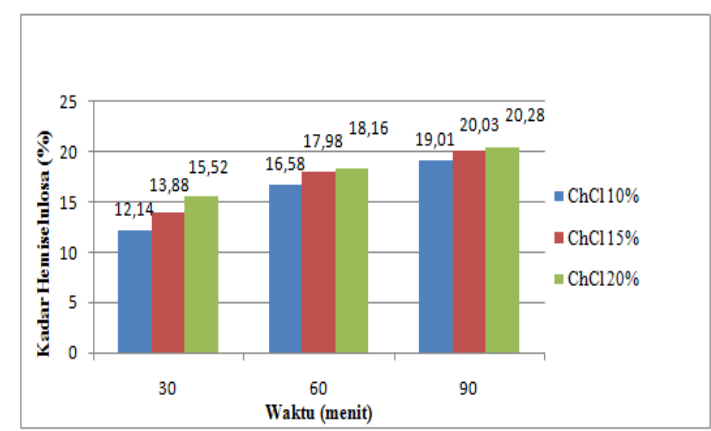

Gambar 1(c). Pengaruh jumlah $\mathrm{ChCl}$ dan Waktu Delignifikasi Terhadap Kadar Hemiselulosa

Dapat dilihat pada Gambar 1(b) dan (c) bahwa kadar selulosa dan hemiselulosa meningkat seiring peningkatan jumlah $\mathrm{ChCl}$ dan waktu delignifikasi. Peningkatan kadar selulosa dan hemiselulosa disebabkan oleh ikatan lignin yang terputus dari biomassa akibat degradasi pada alfa dan beta lignin, sehingga selulosa dan hemiselulosa yang dihasilkan semakin meningkat. Namun, kadar selulosa yang dihasilkan cenderung konstan pada waktu 90 menit dengan junmlah $\mathrm{ChCl}$ lebih dari $15 \%$, hal ini disebabkan karena terjadinya degradasi pada kelompok polisakarida yaitu selulosa dan hemiselulosa yang terkandung pada bahan baku.

Kandungan selulosa yaitu sekitar $45 \%$ - 50\% berat TKKS. Selulosa yang dihasilkan berkisar antara 26,21\% hingga 40,33\%. Sedangkan kandungan hemiselulosa adalah sekitar 26\% - 30\% berat TKKS. Hemiselulosa yang dihasilkan berkisar antara 12,14\% hingga 20,28\%. Dari hasil penelitian ini didapatkan yield selulosa tertinggi dari proses delignifikasi menggunakan $\mathrm{ChCl}$ 
sebesar 80,66\% - 89,62\% dan yield hemiselulosa sebesar $40,06 \%-44,51 \%$.

Perbandingan Kadar Lignin yang Tertinggal di Dalam Holoselulosa Hasil Proses Delignifikasi Menggunakan ChCl dan Tanpa $\mathrm{ChCl}$

Kadar lignin terendah yang tertinggal di dalam holoselulosa yang dihasilkan menggunakan $\mathrm{ChCl}$ sebesar 3,62\%, sedangkan kadar lignin terendah yang tertinggal di dalam holoselulosa yang dihasilkan tanpa menggunakan $\mathrm{ChCl}$ sebesar $18,99 \%$.

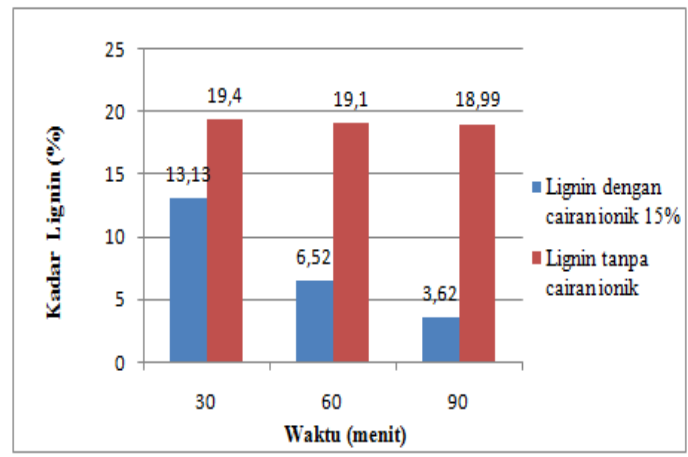

Gambar 2(a). Perbandingan Kadar Lignin yang Tertinggal di Dalam Holoselulosa Hasil Proses Delignifikasi Menggunakan $\mathrm{ChCl}$ dan Tanpa ChCl

Kadar lignin menurun secara signifikan seiring peningkatan jumlah $\mathrm{ChCl}$ dan waktu delignifikasi, sedangkan kadar lignin tanpa $\mathrm{ChCl}$ hanya sedikit menurun dapat dilihat pada Gambar 2(a). Penurunan lignin secara signifikan ini dikarenakan adanya kerja ganda antara $\mathrm{ChCl}$ dan $\mathrm{NaOH}$ yang memutuskan ikatan lignin dari bahan baku untuk meningkatkan senyawa lignin yang terbuang. Sehingga kadar lignin yang tertinggal di dalam holoselulosa semakin sedikit. Namun, kadar selulosa yang tertinggal di dalam holoselulosa hasil delignifikasi menggunakan $\mathrm{NaOH}$ tanpa $\mathrm{ChCl}$ lebih besar, hal ini dikarenakan tanpa adanya bantuan dari $\mathrm{ChCl}$. . Pada penelitian ini diperoleh yield lignin yang tertinggal di dalam holoselulosa hasil delignifikasi menggunakan $\mathrm{ChCl}$ sebesar 79,88\% $81,9 \%$ sedangkan tanpa $\mathrm{ChCl}$ sebesar 5,05\%. Hasil ini diperoleh pada waktu delignifikasi 90 menit.

\footnotetext{
Perbandingan Proses Delignifikasi Menggunakan ChCl dan Tanpa ChCl Terhadap Kadar Selulosa dan Kadar Hemiselulosa

Berikut adalah grafik yang menunjukkan pengaruh perbandingan antara jumlah $\mathrm{ChCl} 15 \%$ dan tanpa $\mathrm{ChCl}$ terhadap kadar selulosa dan hemiselulosa.
}

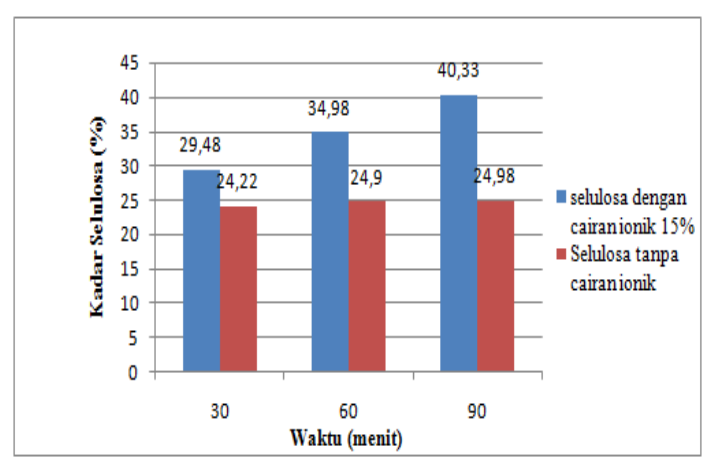

$\begin{array}{lll}\text { Gambar 2(b). Perbandingan } & \text { Proses } \\ \text { Delignifikasi Menggunakan ChCl dan } & \text { Tanpa } \\ \text { ChCl Terhadap Kadar Selulosa } & \end{array}$

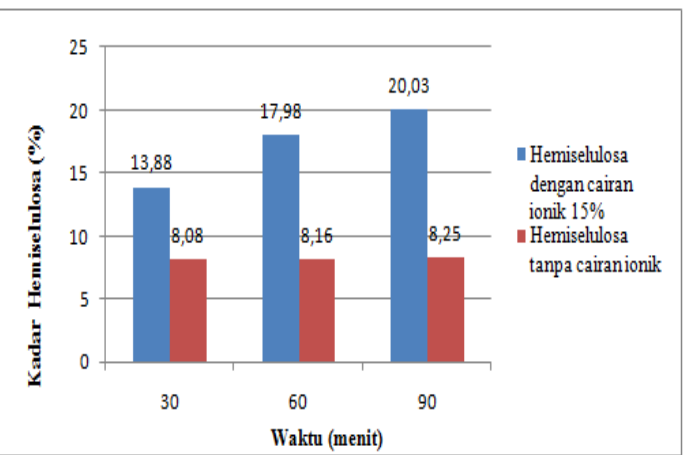

Gambar 2(c). Perbandingan Proses Delignifikasi Menggunakan ChCl dan Tanpa ChCl Terhadap Kadar Hemiselulosa

Pada proses delignifikasi TKKS ini, $\mathrm{NaOH}$ dan $\mathrm{ChCl}$ bekerja sama sebagai larutan pemasak untuk memutuskan ikatan lignin. $\mathrm{ChCl}$ membantu $\mathrm{NaOH}$ meningkatkan kadar selulosa dan hemiselulosa yang dihasilkan. Dapat dilihat pada Gambar 2(a) dan 2(b) bahwa kadar selulosa meningkat secara signifikan dengan menggunakan $\mathrm{NaOH}$ dalam sistem cairan ionik $\mathrm{ChCl}$, sedangkan kadar selulosa yang diperoleh tanpa $\mathrm{ChCl}$ peningkatannya tidak besar, bahkan relatif konstan. Hal ini disebabkan $\mathrm{ChCl}$ bersifat asam mengakibatkan terjadinya degradasi senyawa penyusun lignin sehingga kadar selulosa yang diperoleh semakin meningkat. Sedangkan kadar selulosa yang diperoleh tanpa $\mathrm{ChCl}$ peningkatannya tidak besar disebabkan $\mathrm{NaOH}$ merupakan basa alkali yang memiliki kemampuan melarutkan senyawa organik dan anorganik tidak relatif tinggi.

Hal ini terlihat jelas bahwa delignifikasi menggunakan cairan ionik $\mathrm{ChCl}$ menghasilkan kadar selulosa dan hemiselulosa yang lebih besar dibandingkan tanpa $\mathrm{ChCl}$. Pada penelitian ini diperoleh perbandingan yield selulosa menggunakan $\mathrm{ChCl}$ sebesar 80,66\% - 89,62\% sedangkan tanpa $\mathrm{ChCl}$ sebesar 49,96\% - 55,51\%. Hemiselulosa mendapatkan yield sebesar 40,06\% 44,51\%. sedangkan tanpa $\mathrm{ChCl}$ sebesar $27,5 \%$ $31,73 \%$ pada waktu delignifikasi 90 menit. Proses 
delignifikasi menggunakan cairan ionik $\mathrm{ChCl} 15 \%$ dari berat TKKS pada waktu 90 menit ini mampu meningkatkan derajat delignifikasi sebesar $61,45 \%$ dibandingkan delignifikasi tanpa $\mathrm{ChCl}$.

\section{Pengaruh Perubahan Waktu Reaksi Dan Konsentrasi Kolin Klorid Terhadap Kadar Glukosa}

Proses hidrolisis TKKS dilakukan dalam sistem cairan ionik kolin klorida dengan variasi $\mathrm{ChCl} 10 \%, 15 \%$ dan $20 \%$ berat TKKS dan variasi waktu hidrolisis 30, 60, dan 90 menit. Jumlah kadar glukosa tertinggi yang dihasilkan pada waktu reakasi 90 menit dan $\mathrm{ChCl} 20 \%$ berat TKKS yaitu sebesar 37,96\%. Hasil analisis menunjukkan bahwa jumlah cairan ionik yang berbeda, berpengaruh terhadap kadar glukosa yang dihasilkan. Gambar 3, menunjukkan hubungan antara kadar glukosa dengan jumlah $\mathrm{ChCl}$ dan waktu hidrolisis.

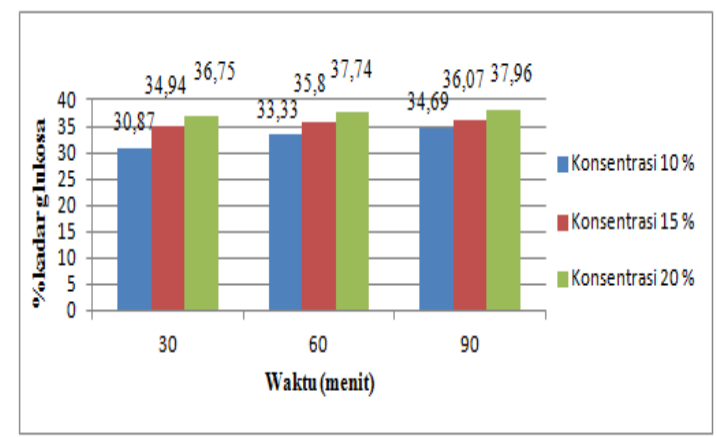

Gambar 3. Pengaruh Waktu Reaksi Dan Konsentrasi Kolin Klorid Terhadap Kadar Glukosa

Dapat dilihat pada Gambar 3 bahwa kadar glukosa semakin meningkat dengan meningkatnya waktu reaksi hidrolisis dan jumlah $\mathrm{ChCl}$. Pada penelitian ini terjadi kenaikan persentase kadar glukosa yaitu 5,8 \% pada waktu 30 menit, 4,4\% pada waktu 60 menit, dan 3,3\% pada waktu 90 menit. Sedangkan untuk kenaiakn jumlah kolin klorid $20 \%$ pada waktu 60 menit ke 90 menit, didapatkan kenaikan kadar glukosa yang tidak signifikan yaitu sebesar $0,22 \%$.

Semakin bertambahnya waktu reaksi, kadar glukosa yang dihasilkan akan semakin bertambah dan sampai pada batas waktu tertentu akan diperoleh kadar glukosa yang maksimum. Ini disebabkan kontak antara zat-zat yang bereaksi dapat lebih lama dan apabila waktu tersebut diperpanjang, pertambahan kadar glukosa sangat kecil bahkan akan menurun. Jika semakin lama waktu reaksi, tidak larut dalam air sehingga tidak dapat berlangsung dengan baik pemecahan rantai polisakarida menjadi glukosa selain itu dapat merusak glukosa yang dihasilkan akibat pemanasan yang terus-menerus. $\mathrm{ChCl}$ mampu mempercepat reaksi hidrolisa dan meningkatkan konversi selulosa dan lignoselulosa menjadi gula. Cairan ionik bereaksi dengan air dan dapat membantu mengikat hemiselulosa agar serat hemiselulosa tidak terikut bersama selulosa dan dapat membentuk senyawa glukosa dengan baik dan karena sifat cairan ramah lingkungan maka dapat mengurangi konsentrasi katalis asam sulfat, sehingga aman bagi lingkungan dan tidak menimbulkan korosif pada alat.

Berdasarkan hasil penelitian yang dilakukan, kadar glukosa optimum diperoleh pada kondisi waktu reaksi hidrolisis 90 menit dan $\mathrm{ChCl} 20 \%$ berat TKKS dengan kadar glukosa yang dihasilkan $37,96 \%$.

\section{Perbandingan Proses Hidrolisa Dengan Menggunakan Cairan Ionik dan Tanpa Menggunakan Cairan Ionik}

Kadar glukosa optimum diperoleh pada kondisi waktu reaksi 90 menit dengan kadar glukosa yang dihasilkan $37,96 \%$ pada $\mathrm{ChCl} 10 \%$ berat TKKS. Sedangkan untuk proses hidrolisis tanpa penggunaan cairan ionik didapat kadar glukosa yang lebih sedikit pada kondisi waktu yang sama yaitu 90 menit sebesar 30,87\% dengan konsentrasi asam sulfat $10 \%$. Pada penelitian ini terjadi kenaikan persentase kadar glukosa yaitu $6,4 \%$ pada waktu 30 menit, 5,2\% pada waktu 60 menit, dan $4,1 \%$ pada waktu 90 menit dengan pemakaian $\mathrm{ChCl} 10 \%$ berat TKKS, seperti ditunjukan pada Gambar 4.

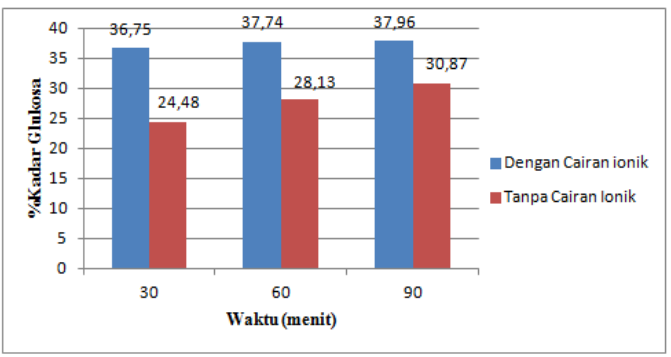

Gambar 4. Perbandingan Kadar Glukosa Proses Hidrolisis Dengan Menggunakan Cairan Ionik dan Tanpa Menggunakan Cairan Ionik

Dapat dilihat pada Gambar 4 bahwa kadar glukosa semakin meningkat dengan meningkatnya waktu reaksi dan didapat kadar glukosa tertinggi dengan menggunakan cairan ionik. Sehingga berdasarkan Gambar 4 kadar glukosa optimum diperoleh pada kondisi waktu reaksi 90 menit dengan kadar glukosa yang dihasilkan 37,96\% dengan $\mathrm{ChCl} 10 \%$ berat TKKS. Sedangkan untuk penggunaan asam sulfat $10 \%$ didapat kadar glukosa yang lebih sedikit pada kondisi waktu yang sama yaitu 90 menit sebesar 30,87\% . Dari data penelitian diatas jumlah glukosa yang diperoleh 4,09\% lebih tinggi dengan menggunakan cairan ionik.

\section{Kesimpulan}

Kesimpulan dari penelitian ini adalah : 
1. Pada roses delignifikasi TKKS menggunakan $\mathrm{ChCl}$ didapatkan yield selulosa sebesar $80,66 \%$ - 89,62\%, hemiselulosa 40,06\% - 44,51\%, dan lignin $79,88 \%$ - $81,9 \%$ pada kondisi terbaik waktu 90 menit dengan jumlah $\mathrm{ChCl} 15 \%$ dari berat TKKS dan mampu meningkatkan derajat delignifikasi sebesar $61,45 \%$ dibandingkan delignifikasi tanpa $\mathrm{ChCl}$.

2. Semakin besar jumlah cairan ionik kolin klorida dan semakin lama waktu hidrolisis maka akan semakin besar pula kadar glukosa yang dihasilkan.

3. Kadar glukosa tertinggi sebesar 37,96\%, diperoleh pada kondisi waktu hidrolisa 90 menit dengan jumlah $\mathrm{ChCl} 20 \%$ berat TKKS, sedangkan tanpa $\mathrm{ChCl}$ diperoleh kadar glukosa sebesar $30,87 \%$.

\section{Daftar Pustaka}

[1] Ahmad sapta Zuidar, dkk, "Kajian Delignifikasi Pulp Formacell Dari Tandan Kosong Kelapa Sawit Mengggunakan Hidrogen Peroksida $\left(\mathrm{H}_{2} \mathrm{O}_{2}\right)$ Dalam Media Asam Asetat," Jurnal Teknologi Industri dan Hasil Pertanian Volume 19 No.2, Juli 2014.

[2] Arif Hendrawan, Pemanfaatan Limbah Tandan Kosong Kelapa Sawit (TKKS) Dalam Pembuatan Bioetanol Dengan Metode Hidrolisis dan Fermentasi, Karya Ilmiah, Program Studi Teknik Kimia Universitas Indonesia, Jakarta 2014.

[3] Dede Ropiah, Pemanfaatan Hidrolisat Tandan Kosong Kelapa Sawit (TKKS) Untuk Produksi Etanol Dengan Pichia Stipitis, Skripsi, Program Sarjana Fakultas Sains dan Teknologi Universitas Islam Negeri Syarif Hidayatullah, Jakarta, 2010.

[4] Hwa-Jeong Lee, Bernardi Sanyoto, JaeWook Choi, Jeong-Myeong Ha, Dong Jin Suh, Kwan-Young Lee, Effects of Lignin on The Ionic Liquid Assisted catalytic Hydrolysis of Cellulose: Chemical Inhibition By Lignin, Springer Science Business, Korea, 2013.

[5] Ida Bagus Wayan Gunam, Pengaruh Perlakuan Delignifikasi Dengan Larutan $\mathrm{NaOH}$ Dan Konsentrasi Substrat Jerami Padi Terhadap Produksi Enzim Selulase Dari Aspergillus niger NRRL A-II, 264, Jurnal Biologi XIV (1) : 55 - 61 Universitas Udayana, Bali, 2010.

[6] Puja Intan Soraya, Produksi Glukosa Dari Tandan Kosong Kelapa Sawit Yang Didelignifikasi Dengan Ozonolysis Pretreatment Melalui Metode Hidrolisis Enzimatik, Seminar Nasional AvoER ke-4 Palembang, 28-29 November 2012.

[7] Silvi Octavia, Pengolahan Awal Lignoselulosa Menggunakan Amoniak Untuk Meningkatkan Perolehan Gula Fermentasi,
Pengembangan Teknologi Kimia untuk Pengolahan Sumber Daya Alam Indonesia Yogyakarta, 22 Februari 2011. 